\title{
Notation Score as Embodied Documentary Presence: A Response to Amelia Jones's "'Presence' in Absentia"
}

Hannah Kosstrin

In response to Amelia Jones's "Presence in Absentia," I would like to reflect upon written dance notation, specifically, Labanotation, as a form of documentation that, as Harmony Bench notes in her introduction to this section,"presences" dance in its own right. Through a written score containing symbols that denote where the body goes in relation to direction, spatial orientation, weight, time, and musicality, Labanotation reproduces multiple dimensions for documenting performance.' As such, it provides documentary and performative traces of the choreographed bodies it mediates. Notation scores are created by people present for the work, but are often read by those in absentia; thus, my reading of Jones's article generated the following questions: Must one be present-in the fleshto witness the dance? Does dance notation create a "being-there?" And if so, what kind of co-presence is established? How is the performative document of notation similar to/ different from a photograph or film?

In terms of historical and theoretical analysis, a notation score and a film of a performance are different kinds of documents. There is a danger, for example, in analyzing a documentary film of a dance (as opposed to a screendance), and considering that filmed version "the dance" instead of recognizing that it is one version of "the dance." Peggy Phelan points out that often we-students, historians, video audiences-get used to a specific filmed version of a performance, and that particular document becomes the work, instead of understanding that the performance was the work and the film is a documentation of it. ${ }^{2}$ Similarly, Ann Hutchinson Guest identifies that a notation score presents the essence of a work due to its ability to capture many performance moments: "Video records an individual performance; notation records the work itself, not the performance of it." 3 Though Guest separates a work's performance from its existence as an entity, her definition opens the documentary scenario to allow the many voices that comprise a score-numerous rehearsals, performances, dancers' and choreographers' input - to become part of a fluid document. This fluidity presences these many elements of the work that could become absent through the passage of time. While a film or even a photograph, as an individual document, captures one performance-arguably preserving a certain performer's charisma that may be lost in a notation score - the plasticity of the notation score as a fluid document allows for many future attempts at presencing the work with different bodies. In doing so, the work has the potential to evolve while referencing a consistent set of symbols.

As a performative document, a notation score offers more information about a choreography or choreographic process than can be contained in photography or film, yet its symbols signify movements that need interpretive translation: Labanotation requires 
literacy. Jones states, "the specificity of knowledges gained from participating in a live performance situation ... should not be privileged over the specificity of knowledges that develop in relation to the documentary traces of such an event." ${ }^{4}$ Though it is a form of documentation, Jones does not encounter in her study of body art a notation score, which is a documentary trace that demands specific knowledge. In order to draw information from a score, the viewer must read notation in order to fully understand what the page portrays. Often, a Laban notator and a director reading the score are different people; one translates through embodiment into notation, one through notation into embodiment. Dancers, moreover, do not necessarily read notation in order to learn a piece from a director who does read the score. While Jones does not include restagings of the work she discusses, her mediation, like that of the director, occurs through her own making sense of the performances from which she was absent through their photographic remnants and documentary traces.

Jones addresses the argument that body art and a documentary photograph need each other to prove the other's existence. ${ }^{5}$ Thus, once the notator has created the notation document, how does she bring a "viewer" into the performance via the documentation? Through reading a notation score and by going through the motions with the body, a reader/viewer creates a new performance through his or her interaction with the document. The notation score, in effect, confirms the performance of a work, but one that unfolds across a series of events that could include rehearsals and performances. ${ }^{6}$ Like the photographer documenting body art, the dance notator is not physically represented in the document, but the document exists as a result of her labor. The notation ghosts the performer-subject's body, while supporting its significance through written signifiers denoting the performers' corporeality.

A person's interaction with a notation document creates a mediated reproduction of a performance. As Bench asserts in this discussion, photographs and screendance are sites of performance. The score is also a site of performance; it displays aspects of a work that may be missed by viewing it live, and it exists as a set of edited decisions that left parts of the work, or ways of articulating it, so to speak, on the cutting room floor. In the score of Anna Sokolow's Kaddish, for example, the words of the Jewish Mourners Kaddish visibly interweave between and rely upon the movements (via symbols) in a way that is not as overt as performance. This documentary choice highlights the centrality of the Kaddish prayer's rhythmic patter (which is linked to its spiritual effect) to the dance. ' In the interactive score for Bebe Miller's Prey, ${ }_{1}^{8}$ furthermore, "Bebe Notes" in the score's margin correspond to video clips on a companion DVD featuring Miller's explanations as to how to perform certain movements. ${ }^{9}$ In contrast to a documentary performance site with an often-absent choreographer, the Prey score presences Miller's physicality. The notators for these scores, Lynne Weber and Valarie Williams, made editing decisions on how to represent the dance on the page such that future directors and dancers can effectively re-presence it. Neither the dancing body nor the notation score contains all the information that comprises the complete work. It is through the intermingling —or co-presencing_of a director's fleshy embodiment with the information laid out in the score that a dance is fully presenced.

This co-presence as a result of interaction is also reflected in Jones'encounters with the photographic and filmic documents of the performances she discusses. Jones references Roland Barthes' having-been-there of a photograph, ${ }^{10}$ the notion that by seeing an image, 
a viewer experiences its temporal presence. ${ }^{11}$ Similarly, a Labanotation score creates an embodied or a time-lapse of, being-there, since a notator is usually present for numerous rehearsals or performances of a dance in generating a score. First the notator, and later the reader/director, must go through the motions of the performance, launching herself into a kinesthetic sensation of the work from the inside out in order to fully engage with the notation score as a performance document.

Jones articulates her experiences of body art, including Annie Sprinkle's Public Cervix Announcement, which she knows both through photographic record and via live performance, and Carolee Schneemann's Interior Scroll, which she only knows through documents. However, Jones knows neither of these performances from the inside. The notation score offers a third kind of presencing to the photographic record and the live event: it becomes a document of a performance's innards. While it does not reproduce, for example, the audience's experience of gazing into Sprinkle's cervix, ${ }_{12}^{12}$ or watching Schneemann extract the long paper chain from her vagina, ${ }^{13}$ as does a photograph, if a notated score existed, it might offer instructions for reproducing Sprinkle's and Schneemann's experiences of performing these works, thus replicating the events from the performers' perspectives. The score becomes a documentary intermediary through which a reader embodies distinct traces of a work that she may or may not have experienced in fleshy performance, yet she brings her own flesh into the document through reading/performing the score and gaining an internal (performative) understanding of the work.

Because a dance notation score is written, as it were, from the inside of a performance, it offers its readers aspects of a work that are less accessible from a video document of a dance. The traces of movements' intention and initiation that the symbols portray are not always evident in a video, or even in watching a performance, especially if a movement is subtly initiated from within or if the movement does not clearly manifest the intention. Additionally, a score often contains a glossary with the notator's comments about the dance's background, motivation for moments as dictated by the choreographer, and notes about dancers' timing.

Dance, like body art, is an ephemeral form that relies on the moment of performance, as well as its disappearance, ${ }^{14}$ and on the people involved with it, to presence it. Phelan notes, "Performance's potency comes from its temporariness, it's [sic ] 'one time only' life."15 Jones shows the pertinence of performance's potency through her discussion of her absence and presence of experiencing body art through photographic documents and live performance. One cannot reconstitute a performance moment. Yet, through mediation of the space in/as performance document, Labanotation presences dance-and along with coached versions of the dance passed down from dancer to dancer and photographs of it, a viewer/reader can re-presence that from which she was initially absent.

\section{References}

Hutchinson Guest, Ann. Labanotation: The System of Analyzing and Recording Movement. $4^{\text {th }}$ ed. New York: Routledge, 2005.

Jones, Amelia. "'Presence' in Absentia: Experiencing Performance as Documentation." Art Journal, 56, no. 4 (1997): $11-18$.

Jordan, Stephanie, ed. Preservation Politics: Dance Revived, Reconstructed, Remade. London: Dance Books, Ltd., 2000. Phelan, Peggy. Unmarked: The Politics of Performance. New York: Routledge, 1993. 
Thomas, Helen. "Reconstruction and Dance as Embodied Textual Practice." In Rethinking Dance History: A Reader. Edited by Alexandra Carter. New York: Routledge, 2004. 32-45.

Weber, Lynne, notator. Kaddish. Choreographed by Anna Sokolow. 1974. New York: Dance Notation Bureau, 1980. Notation graphics by Mira Kim, 2007.

Williams (Mockabee), Valarie, notator. Prey. Choreographed by Bebe Miller. 2002. New York: Dance Notation Bureau, 2005.

, dir. Prey: An Innovation in Dance Documentation: Enhanced Process Based Instruction: Companion DVD-Video for the Labanotation Score Prey. Chor. Bebe Miller. 2001. The Ohio State University Department of Dance, 2005.

\section{Notes}

1. Close analysis of Labanotation reveals the biases of its early twentieth century Western cultural roots.

2. Phelan, Unmarked, 31.

3. Hutchinson Guest, Labanotation, 6.

4. Jones, "'Presence' in Absentia," 12.

5. Ibid., 16.

6. Dance scholars have taken up the issue of historical bodies in debating processes for and determining authenticity of reconstructing dances for a contemporary stage. Issues of reconstruction include how to make an established dance relevant to contemporary audiences; how much to change movement to fit dancers' bodily and training abilities; how to capture the essence of a dance long after its first performance; and how to balance information from a notated score, if there is one, with kinesthetic memories of dancers who performed the piece or otherwise had a bodily knowledge of it. See Thomas, "Reconstruction and Dance" and Jordan, ed., Preservation Politics.

7. See Weber, Kaddish.

8. See Williams notator, Prey.

9. See Williams dir., Prey: An Innovation in Dance Documentation.

10. Jones, "'Presence' in Absentia," 16.

11. Roland Barthes, "Rhetoric of the Image," Image-Music-Text (1977): 44-45, quoted in Jones, "'Presence' in Absentia," 16.

12. See Jones, "'Presence' in Absentia," 16-17.

13. See Ibid., 12-13.

14. Phelan, Unmarked, 146.

15. Ibid., 178 . 